\title{
Hydrolysis of corn stover pretreated by DESs with carbon-based solid acid catalyst
}

\author{
Shuanglan $\mathrm{Hu}^{1} \cdot$ Fei Meng ${ }^{1}$ - Dongting Huang ${ }^{1}$. Junsheng Huang ${ }^{1}$ ' Wenyong Lou ${ }^{2}$
}

Received: 5 January 2020 / Accepted: 9 June 2020 / Published online: 18 June 2020

(C) The Author(s) 2020 OPEN

\section{Abstract}

This study evaluated two hydrolysis strategies that involve a two-step and a one-pot process for the hydrolysis of cellulose. The two-step process consisted of cellulose pretreatment with deep eutectic solvent, followed by hydrolysis promoted by the carbon-based solid acid catalyst. The obtained results showed that the xylose and glucose yields were $33.9 \%$ and $6.9 \%$, respectively, from corn stover based on this two-step strategy with $\mathrm{ChCl}$. Formic acid used as the pretreatment solvent. For one-pot hydrolysis, side reactions occurred and less glucose accumulated in the reaction system. In this case, the maximum achieved glucose yield was $21.1 \%$ for the hydrolysis of microcrystalline cellulose.

Graphic abstract The corn stover was pretreated with DES and then hydrolysed by carbon-based solid acid catalyst. Approximately $33.9 \%$ of xylose and $6.9 \%$ of glucose was recovered from corn stover with ChCl.Formic acid as the pretreatment solvent.

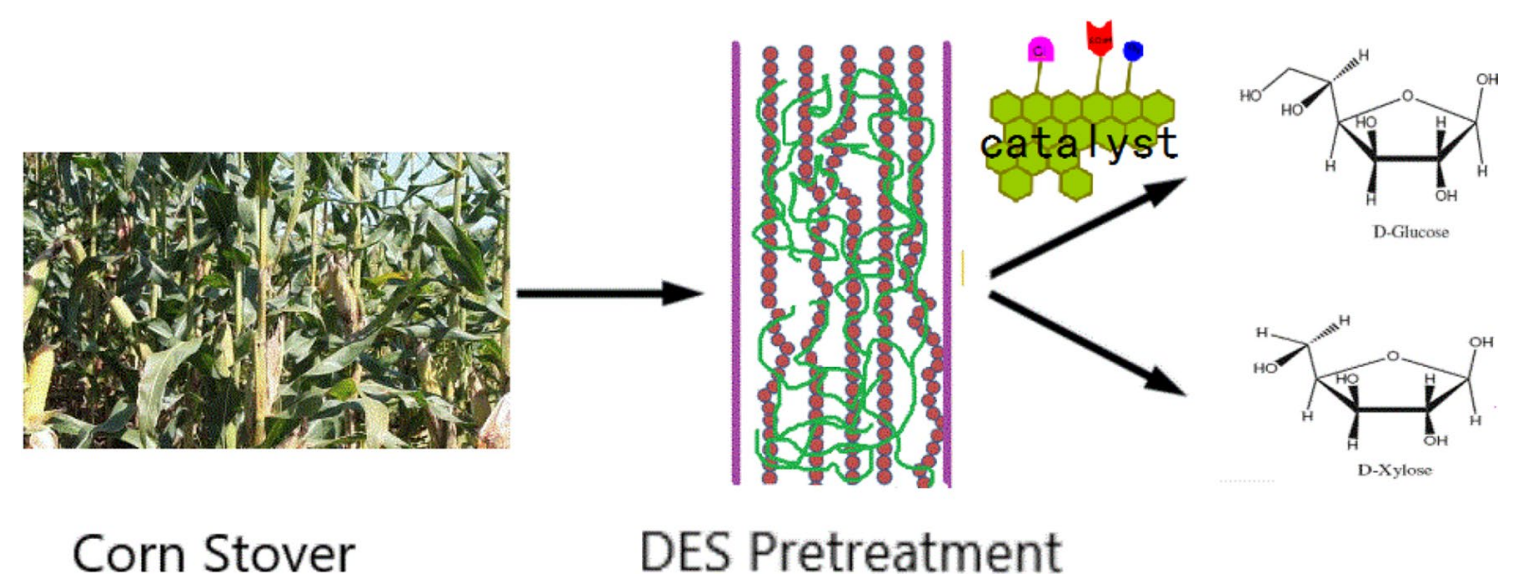

Keywords Deep eutectic solvents · Pretreatment of lignocellulose $\cdot$ Hydrolysis of cellulose $\cdot$ Heterogeneous catalyst

$\triangle$ Junsheng Huang, 13602770706@163.com; $\varangle$ Wenyong Lou, wylou@scut.edu.cn | ${ }^{1}$ Guangdong Provincial Engineering Research Center for Green Technology of Sugar Industry, Guangdong Provincial Bioengineering Institute (Guangzhou Sugarcane Industry Research Institute), Guangzhou, China. ${ }^{2}$ School of Food Science and Engineering, South China University of Technology, Guangzhou 510640, China. 


\section{Introduction}

Meeting the continuously increasing demand for clean energy is the greatest current challenge in energy research [1]. Amongst the many renewable sources of energy, energy from the biomass is one of the most abundant sources due to the wide availability of raw materials. The use of lignocellulose may solve the crisis of food shortage caused by the use of a food crop as a resource for producing fuel and chemicals [2].

Lignocellulose is a promising alternative to food crops as a biomass source. Simple and efficient reduction of lignocellulose to sugars such as glucose and xylose by hydrolysis is the greatest challenge in the use of lignocellulose for energy production due to the recalcitrant nature of lignocellulose [3]. As pointed by Liu et al., the development of efficient, sustainable and economic methods for cellulose depolymerisation is a key advance for biorefining [4].

In recent years, researchers have investigated various methods for the pretreatment of lignocellulose [5]. For example, the biomass was treated with different ionic liquids to separate the main components of the biomass [6], or the lignocellulose was directly dissolved in an ionic liquid, followed by the addition of an anti-solvent to induce precipitation [7].

The use of certain ionic liquids (ILs), and more recently, deep eutectic solvents (DESs), has arisen as a new technology for the pretreatment of lignocellulose [8]. In recent years, much research has focused on the possibility of pretreatment of lignocellulose by ionic liquids [9]. Ionic liquids are broadly defined as salts with a melting point below $373 \mathrm{~K}$. These compounds tend to have low vapour pressure and high thermal stability, and they are considered to be environmentally friendly. Their ionic properties allow them to simultaneously dissolve both organic and inorganic compounds, facilitating different separation processes. Studies have shown that ionic liquids can enhance the pretreatment of biomass [10]. Recently, Ninomiya et al. [11] studied the reproducible choline-carboxylic acid ionic liquid pretreatment of kenaf core and bamboo powder and found that for these lignocellulosic feedstocks pretreated by choline-formic acid $(\mathrm{H})$ and choline-acetic acid] (Ch.OAc) at $383 \mathrm{~K}$ for $16 \mathrm{~h}$, a fraction of hemicellulose was cracked and the degradation degree of cellulose reached $100 \%$ in the residue after pretreatment, which is comparable to the results obtained using the Emim.OAc ionic liquid pretreatment. It was also found that these regenerable ionic liquids had an inhibitory effect on the growth of S. cerevisiae MT8-1 that was far weaker than the effect of Emim.OAc. At the same time, new ionic liquids are being continuously developed, for example Emim.DEP, $\mathrm{HEMA} \cdot \mathrm{MeSO}_{4}$, which shows excellent compatibility with cellulose and microbial matter. It is well-known that pure ionic liquids have higher viscosity that is not favourable for practical use. Therefore, in recent years, there have been attempts to add water to the ionic liquids to reduce their viscosity. At the same time, due to the reduction of the pretreatment intensity, the loss of polysaccharides has been reduced. For example, Fu et al. [12] mixed rye straw with 50\% Emim. OAc -water and treated it at $423 \mathrm{~K}$ for $40 \mathrm{~min}$, obtaining a yield of reducing sugar of $81 \%$. BMIm.MeSO ${ }_{4}, \mathrm{BMIm} \cdot \mathrm{HSO}_{4}, \mathrm{MMIm} \cdot \mathrm{OAc}$, $\mathrm{MMIm} \cdot \mathrm{Cl}, \mathrm{MMIm} \cdot \mathrm{MeSO}_{3}, \mathrm{MMIm} \cdot \mathrm{OTf}$ ionic liquid-water mixtures were used for the pretreatment of hardwood and coniferous pine by Brandt et al. [13] Their results showed that the addition of water did not significantly reduce the lignin extraction capacity of the ionic liquid, and the yield of reducing sugar from the recovered slag was higher than the yield of reducing sugar from the pretreatment using the pure ionic liquid. Intermolecular and intramolecular hydrogen bonds of cellulose were considered to be broken and replaced by hydrogen bonds consisting of ionic liquid anions and carbohydrate hydroxyl groups. In contrast, traditional pretreatment methods require longer saccharification times and higher enzyme loads to achieve the same sugar yield. [14]. Moreover, many conventional pretreatment methods will generate numerous by-products that in turn affect the fermentation process [7]. Although some ionic liquids can dissolve lignocellulose without producing large amounts of by-products [15], they are still unsuitable for commercial applications. Ionic liquids are expensive, and require high energy consumption for separation and recovery; moreover, their toxicity and high viscosity also hinder their commercial application [16]. Recently, deep eutectic solvents (DESs), which are new ionic liquid (IL) analogues derived from natural and renewable components, have been identified as potential alternative green solvents for lignocelluloses pretreatment [17]. DESs exhibit similar physicochemical properties to classical ILs but show additional advantages such as easy preparation, simple purification processes and utilization of renewable materials [18]. In 2017, Hou et al. [19] reported a high performance two-stage deep eutectic solvent synergistic pretreatment method and significantly enhanced enzymatic hydrolysis of rice straw. It was also found that the DESs containing more hydroxyl or amino groups had detrimental impacts on the pretreatment efficiency, while the presence of strong electron-withdrawing groups enhanced the DESs performance [20].

Solid acid catalysts have been widely applied as additives to promote the rate of lignocellulose hydrolysis. Scientists have prepared many solid catalysts derived from 
biomass that generally include the process to transform the biomass into porous carbon [21-23]. For example, Su et al. reported the synthesis of a chemically functional magnetic carbonaceous acid catalyst for fermentable sugars production from sugarcane bagasse [24]. However, the enzyme catalysed hydrolysis reaction was uneconomical due to the lack of stability of the catalysts. Solvents used for pretreatment must be thoroughly removed from the system to ensure that the regenerated cellulose will not affect the enzyme catalyst. Therefore, we chose to address this problem by combining the novel DES with a stable solid acid catalyst. In this work, a bifunctional carbonbased solid acid catalyst was applied to the hydrolysis of pretreated biomass for glucose production. However, the structure and property of catalysts are not the main focus of this work, rather the system combining DES pretreatment and solid acid catalysts was first explored in this work.

\section{Materials and methods}

\subsection{Synthesis of DESs}

The reagents with their corresponding masses were weighed accurately according to their molar ratio (Table 1). Then, the mixture was heated to $363 \mathrm{~K}$ in an oil bath and maintained at this temperature for 2-4 $\mathrm{h}$ until the formation of a stable, uniform, translucent solution. The mixture was cooled to room temperature and then dried in a vacuum oven at $343 \mathrm{~K}$ for $48 \mathrm{~h}$.

\subsection{Pretreatment of cellulose and lignocellulose}

Microcrystalline cellulose or corn stalks (200 mg) were added to various ionic liquids ( $5 \% \mathrm{w} / \mathrm{w}$ solids addition, $4 \mathrm{~g}$ ) and stirred at 353-393 K for $24 \mathrm{~h}$. Then, deionized water $(10 \mathrm{~mL})$ was added to the cellulose-ionic liquid system, and the resulting precipitate was washed with deionized water, centrifuged, washed, and lyophilized.

Table 1 Compositions and mole ratio of synthesized DESs

\begin{tabular}{llllc}
\hline Cation & Molecular mass & Ratio & Anions & Molecular mass \\
\hline $\mathrm{ChCl}$ & 193.63 & $1: 2$ & Urea & 60.06 \\
$\mathrm{ChCl}$ & 193.63 & $1: 2$ & Glycerol & 92.09 \\
$\mathrm{ChCl}$ & 193.63 & $1: 1$ & Malonic acid & 104.06 \\
$\mathrm{ChCl}$ & 193.63 & $1: 2$ & Formic acid & 46.03 \\
$\mathrm{ChCl}$ & 193.63 & $1: 2$ & Ethylene glycol & 62.03 \\
$\mathrm{ChCl}$ & 193.63 & $1: 4$ & 1,4 -butanediol & 207.5 \\
$\mathrm{ChCl}$ & 193.63 & $1: 1$ & Citric acid & 192.14 \\
$\mathrm{ChCl}$ & 193.63 & $1: 1$ & Oxalic acid & 90.04 \\
\hline
\end{tabular}

\subsection{Preparation of the solid acid catalyst}

The solid acid catalysts used in this research were prepared according to the method reported by Hu et al. [21] Sucralose was carbonized at $673 \mathrm{~K}$ under nitrogen for $0.5 \mathrm{~h}$ to obtain a black solid powder. The tube-type atmosphere furnace was cooled to below $273 \mathrm{~K}$ and the obtained black solid powder $(5 \mathrm{~g})$ was sulphonated with concentrated sulphuric acid ( $50 \mathrm{~mL}, 96 \%)$ at $423 \mathrm{~K}$ for $15 \mathrm{~h}$ under nitrogen and then cooled to room temperature. The solid solution of the solid precipitate and concentrated sulphuric acid was slowly added to distilled water $(1000 \mathrm{~mL})$ at room temperature. Stirring was continued during the pouring and then the solid was filtered under reduced pressure and repeatedly washed with hot distilled water (>253 K) until the liquid contained no $\mathrm{SO}_{4}{ }^{2-}$. Then, the black solid was dried in a vacuum oven at $253 \mathrm{~K}$ for $24 \mathrm{~h}$ to obtain the desired carbon-based solid acid catalyst. Characterization data of the prepared solid acid catalysts were analysed in detail in a previous work [25].

\subsection{Hydrolysis reaction}

Microcrystalline cellulose or corn stover $(0.05 \mathrm{~g})$, catalyst $(0.1 \mathrm{~g})$ and deionized water $(4 \mathrm{~mL})$ were added into a $10 \mathrm{~mL}$ flask with a condenser pipe to prevent the loss of water evaporation. After stirring for $1 \mathrm{~min}$, the flask was placed in an oil bath and heated to $363 \mathrm{~K}$ for a certain time. At each point in time, $1.5 \mathrm{~mL}$ of the mixture was removed and transferred to a $2 \mathrm{~mL}$ centrifuge tube. The mixture was analysed by HPLC.

\subsection{Product analysis}

Glucose and cellulose were analysed using an HPLC system consisting of a Waters 515 HPLC pump using a BioRad organic acid column, and a Waters 2410 refractive index detector. The column used was a $300 \mathrm{~mm} \times 7.8 \mathrm{~mm}$, Aminex HPX-87H (BIO-RAD Laboratories, Hercules, CA, USA). The original glucose content, namely, the theoretical yield of glucose was calculated from the weight of cellulose revised by a conversion factor of 0.9 ; the same method was used for xylose albeit with a conversion factor of 0.88 . Calibration curves obtained by analysing standard solutions with known concentrations were applied to determine the concentration of each compound in the liquid phase. Error bars represent the standard deviations of the results of three experiments.

\subsection{One-pot hydrolysis}

Microcrystalline cellulose $(0.1 \mathrm{~g})$, carbon-based solid acid catalyst $(0.1 \mathrm{~g})$ and either ionic liquid $(4 \mathrm{~g})$ or deep eutectic 
solvent $(4 \mathrm{~g})$ or distilled water $(4 \mathrm{~mL})$ were added to $10 \mathrm{~mL}$ vials and sealed with an aluminium lid and then heated at $353 \mathrm{~K}$ for $0-30 \mathrm{~h}$.

\subsection{Reusability of the solid acid catalyst in one-pot hydrolysis}

After the hydrolysis reaction, the solid catalysts were separated from the reaction mixture by filtration. The filter residue was washed repeatedly with distilled water and dried in a vacuum drying oven over $24 \mathrm{~h}$; this residue was subsequently used for the reaction.

\subsection{Characterization}

The size and morphology of the synthesized sucralosederived carbon based catalyst were characterized by scanning electron microscopy (SEM) analysis using a JSM-5600 LV microscope (ZEISS Merlin, Germany). The structure of the synthesized catalyst was analysed using X-ray powder diffraction (XRD) patterns measured with a D/max 2550 $X$-ray Diffractometer (Rigaku, Japan) using Cu Ka radiation $(\lambda=0.1541 \mathrm{~nm})$ in steps of $0.05^{\circ}(2 \theta) \mathrm{min}^{-1}$ from $10^{\circ}$ to $70^{\circ}$

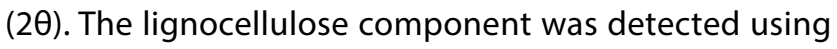
the National Renewable Energy Laboratory's method for the detection of carbohydrates. Dry lignocellulosic powder $(0.30 \mathrm{~g})$ was mixed with of $72 \mathrm{wt} \%$ sulphuric acid solution $(3.0 \mathrm{~mL})$, the mixture was stirred at $303 \mathrm{~K}$ for $60 \mathrm{~min}$, and the distilled water $(84.0 \mathrm{~mL})$ was added, and the mixture was reacted at $394 \mathrm{~K}$ for $1 \mathrm{~h}$. The content of polysaccharide in the sample was evaluated by high-performance liquid chromatography (HPLC). The absorbance at $320 \mathrm{~nm}$ was measured and the lignin content was calculated from the absorbance coefficient of $30 \mathrm{~L} /(\mathrm{g} \mathrm{cm})$. The remaining insoluble residue was dried to a constant weight at $378 \mathrm{~K}$ and $848 \mathrm{~K}$ in order to calculated the acid-insoluble lignin content.

\section{Results and discussion}

\subsection{Effect of pretreatment solvents on reducing sugar yield}

First, we used microcrystalline cellulose (Sigma-Aldrich, DP200) as a model reactant to evaluate the pretreatment efficiency of some common solvents used for lignocellulose treatment. It is observed from Fig. 1 that among these six solvents, Emim.OAc was the most suitable solvent for MCC pretreatment (glucose yield of $54.6 \%$ obtained after $24 \mathrm{~h}$ of reaction). $\mathrm{ChCl}$.formic acid reached the highest glucose yield (42.9\%) with SUCRA-SO ${ }_{3} \mathrm{H}$ as the catalyst after $24 \mathrm{~h}$ of reaction and was better than the other tested deep eutectic solvents. The glucose yield from microcrystalline cellulose pretreated by DESs with malonic acid (11.7\%), glycerol (4.0\%) or urea (4.9\%) as anions was only slightly higher than that for the non-pretreatment samples (2.0\%), suggesting that the pretreatment ability of DESs with alcohols as anions was inferior to the DESs with organic acids as anions when choline chloride was cationic.

Then, we used corn stover as the reactant to evaluate the pretreatment efficiency of the examined solvents. Since the cellulose in the corn stover was firmly wrapped in the network structure consisting of lignin and hemicellulose, it was difficult to expose the cellulose to the solid acid catalyst. We hoped that through the treatment process, the structure of lignocellulose would become looser and more amorphous, favouring the contact between the catalytic activity centre $\left(-\mathrm{SO}_{3} \mathrm{H}\right.$ group) with $\beta-1,4-$ glucoside (reaction site), and the crystallinity of cellulose would decrease, increasing the yield of reducing sugars. Relevant structure analyses were necessary for further study.

Comparison of Figs. 2 and 3 shows that regardless of the solvent adopted, the xylose yield was higher than that of glucose, suggesting that the hydrolysis of hemicellulose was much easier than hydrolysis of cellulose for this carbon-based solid acid catalyst.
Fig. 1 Hydrolysis of MCC pretreated by different solvents. Reaction conditions: $0.05 \mathrm{~g}$ MCC, $0.1 \mathrm{~g}$ solid acid catalyst and $4 \mathrm{~mL}$ deionized water, $363 \mathrm{~K}$

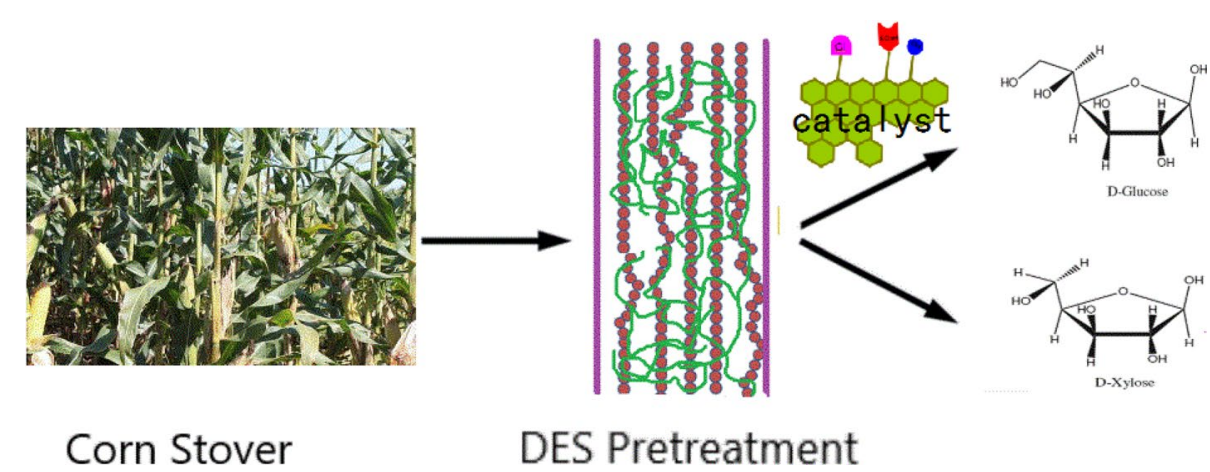

Corn Stover 


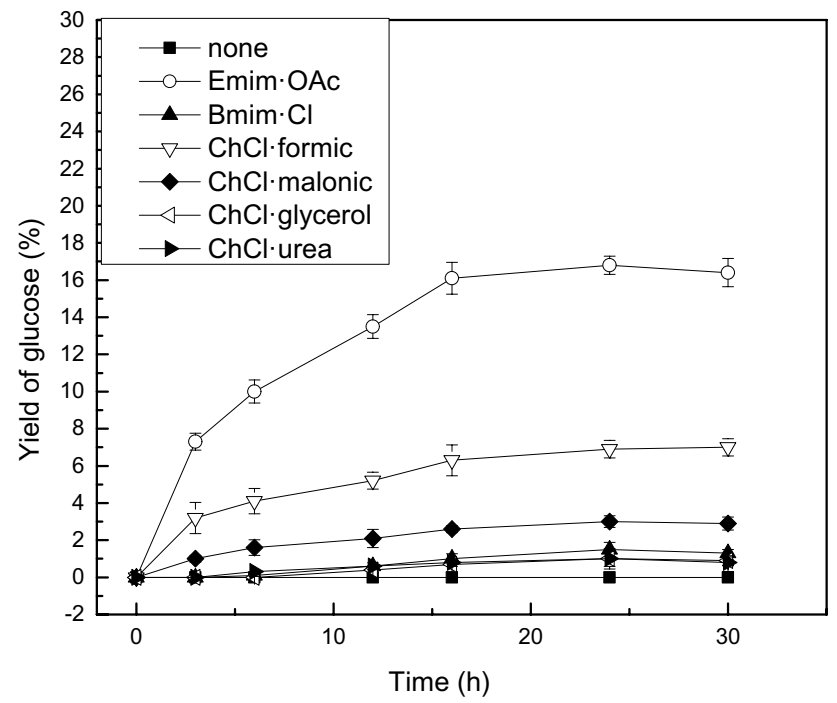

Fig. 2 Glucose yield from corn stover before and after pretreatment. Reaction conditions: $0.05 \mathrm{~g}$ corn stover, $0.1 \mathrm{~g}$ solid acid catalyst and $4 \mathrm{~mL}$ deionized water, $363 \mathrm{~K}$

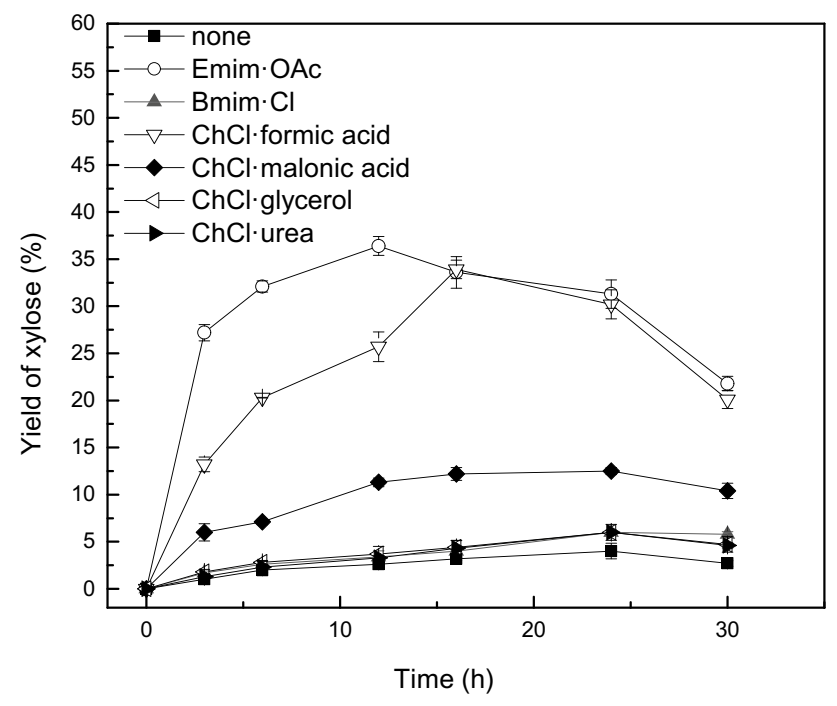

Fig. 3 Xylose yield from corn stover pretreated by different solvents. Reaction conditions: $0.05 \mathrm{~g}$ corn stover, $0.1 \mathrm{~g}$ solid acid catalyst and $4 \mathrm{~mL}$ deionized water, $363 \mathrm{~K}$

\subsection{Effect of pretreatment conditions on reducing sugar yield}

Figure 4 shows the effect of the pretreatment temperature on the sugar yield. It was found faster glucose generation was obtained with higher pretreatment temperature for Emim.OAc. However, the final glucose yields for different pretreatment solvents were roughly the same when the reaction time was long enough (Fig. 4). However, for $\mathrm{ChCl} \cdot$ formic acid treatment, the difference in the

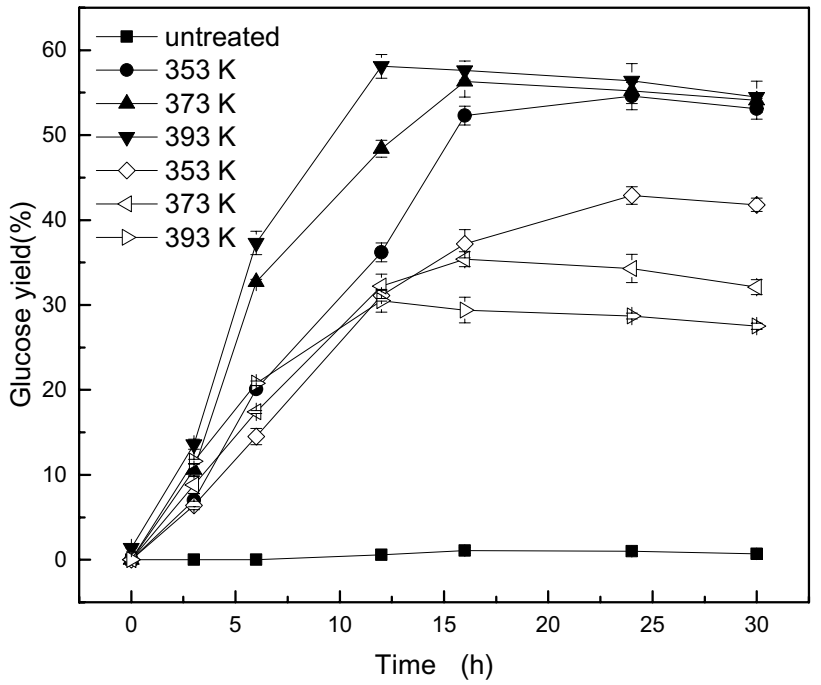

Fig. 4 Glucose yield from MCC pretreated at different temperatures with Emim.OAc (closed symbols) and with $\mathrm{ChCl} \cdot$ formic acid (open symbols). Reaction conditions: $0.05 \mathrm{~g} \mathrm{MCC}, 0.1 \mathrm{~g}$ solid acid catalyst and $4 \mathrm{~mL}$ deionized water, $363 \mathrm{~K}$

pretreatment temperature strongly affects the final yield (the maximum glucose yield was $42.9 \%$ when MCC was pretreated at $353 \mathrm{~K}$ ). This distinction between Emim.OAc and $\mathrm{ChCl} \cdot$ formic acid may be due to their different pretreatment mechanisms. It was reported that the possible mechanism of dissolution of cellulose by quaternary ammonium salts involved the reaction of the quaternary ammonium ions with the oxygen in the hydroxyl groups on the cellulose, forming a complex structure and thus accelerating the degradation of the cellulose crystallinity [26]. For Emim.OAc, higher temperature facilitated the contact of the ionic liquid with the cellulose, and an increasing amount of microcrystalline cellulose irreversibly dissolved in the IL solvent, resulting in the decrease of the overall crystallinity of the regenerated cellulose [27]. However, the amorphous area that enabled easy acid catalysed hydrolysis will likely be lost during the regeneration. Therefore, although the rate of reaction was increased, the final yield of glucose changed weakly (from 54.6 to $58.1 \%$ ). For microcrystalline cellulose pretreated with $\mathrm{ChCl}$.formic acid, the viscosity of the solvent decreases with increasing temperature [28]. As the pretreatment temperature increased, the amount of glucose produced from the regenerated cellulose catalysed by the carbon-based solid acid catalyst increased [29].

As observed from Fig. 5, when the pretreatment time was as short as one hour, for both the deep eutectic solvent ( $\mathrm{ChCl} \cdot$ formic acid) and the ionic liquid (Emim.OAc) used as the pretreatment solvent, the yield of glucose was significantly lower than that obtained using a longer pretreatment time. The highest glucose yield reached 1.3\% 


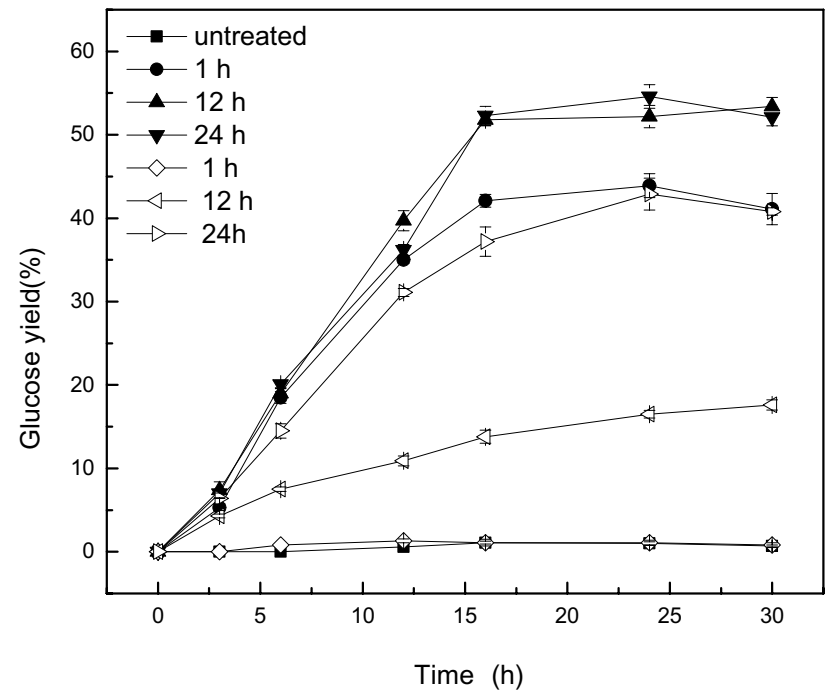

Fig. 5 Glucose yield from MCC pretreated for different times with Emim.OAc (closed symbols) and with ChCl.formic acid (open symbols). Reaction conditions: $0.05 \mathrm{~g}$ MCC, $0.1 \mathrm{~g}$ solid acid catalyst and $4 \mathrm{~mL}$ deionized water, $363 \mathrm{~K}$

after $1 \mathrm{~h}$ pretreatment with $\mathrm{ChCl} \cdot$ formic acid, and the highest glucose yield reached $17.6 \%$ after pretreatment for $12 \mathrm{~h}$. After pretreatment for $24 \mathrm{~h}$, the highest glucose yield reached $42.9 \%$. For Emim.OAc, the highest glucose yield reached $43.9 \%$ after $1 \mathrm{~h}$ pretreatment. After $12 \mathrm{~h}$, the highest glucose yield reached $53.4 \%$. After $24 \mathrm{~h}$ pretreatment, the highest glucose yield reached $54.6 \%$. For these two solvents, prolonging the pretreatment time from $12 \mathrm{~h}$ to $24 \mathrm{~h}$ had only a limited effect on the efficiency of hydrolysis catalysed by the carbon-based solid acid catalyst.

\subsection{Optimization of the pretreatment solvent}

Many studies have investigated the application of Emim.OAc in high-value utilization of biomass. Here, we focus on developing the potential application of $\mathrm{ChCl}$.formic acid. It was reported that the ratio of hydrogen bond receptors and hydrogen bond donors affects the intermolecular hydrogen bonds between DES and lignocellulose and thus affects the pretreatment results [30]. An examination of Fig. 6 shows that the optimal HBA:HBD ratio for $\mathrm{ChCl}$.formic acid was 1:2.

Water played the role of the $\mathrm{H}$-bond acceptor in the structure of DES. An increased water content will lower the cost of the DES pretreatment solvent and will reduce the viscosity of the reaction mixture. However, excess water will destroy the intermolecular hydrogen bonding in the DES solvent and then will influence the effectiveness of the pretreatment. By comparing the $\mathrm{ChCl}$.formic acid-water mixtures with different water contents, we found that $30 \%(\mathrm{v} / \mathrm{v})$ water gave the highest sugar yield

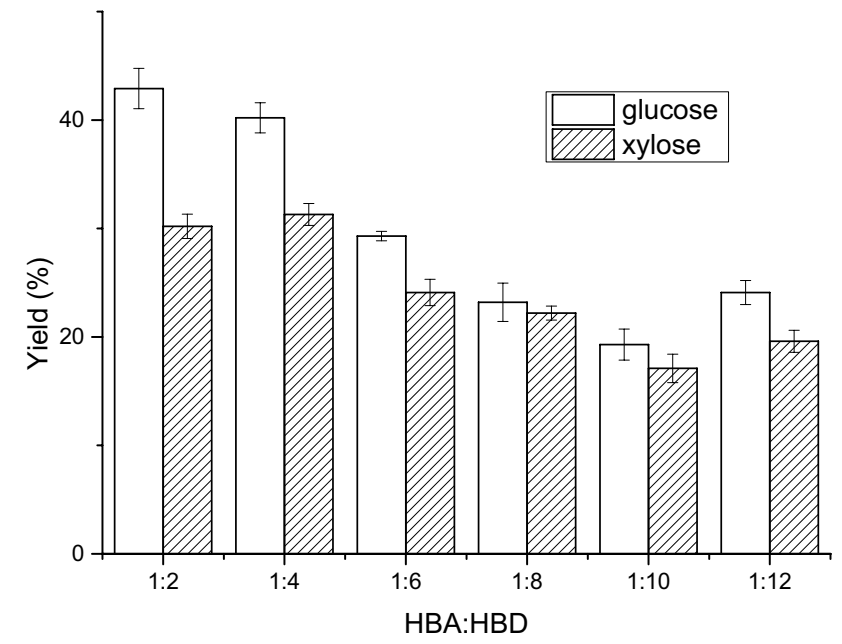

Fig. 6 Glucose and xylose yield from solid acid catalysed hydrolysis of corn stover pretreated by $\mathrm{ChCl}$.formic acid with different HBA:HBD ratio. (Hollow column: Glucose yield from pretreated MCC, Shadow column: xylose yield from pretreated corn stover). Reaction conditions: $0.05 \mathrm{~g}$ MCC or corn stover, $0.1 \mathrm{~g}$ solid acid catalyst and $4 \mathrm{~mL}$ deionized water, $363 \mathrm{~K}$

(glucose: $46.4 \%$ and xylose: $36.1 \%)$, followed by $10 \%(\mathrm{v} / \mathrm{v})$ (glucose: $43.6 \%$ and xylose: $35.9 \%$ ) and $20 \%(v / v)$ (glucose: 44.9\% and xylose: $35.7 \%$ ) (Fig. 7).

\subsection{Structural changes due to the pretreatment}

An examination of the data presented in Table 2 shows that the hemicellulose content in corn stover decreased

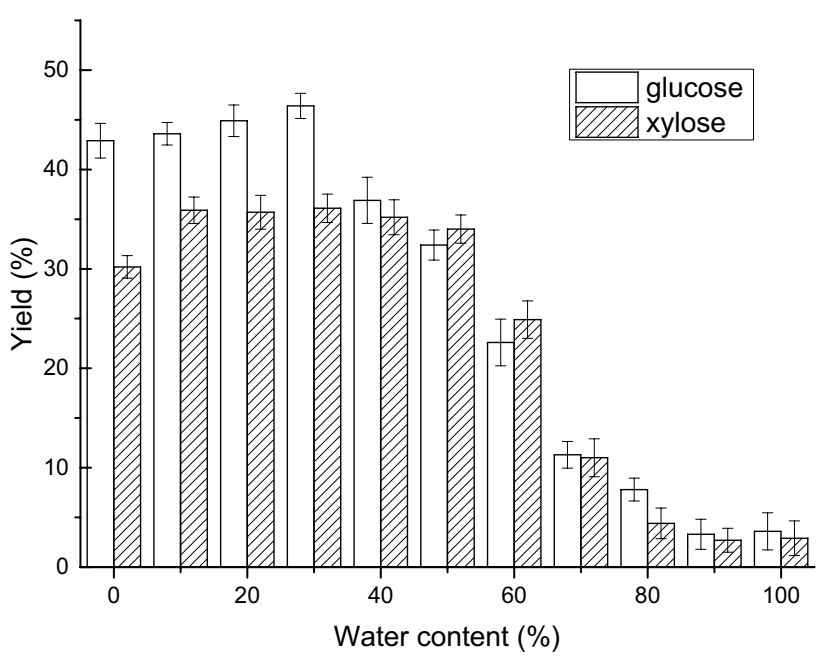

Fig. 7 Effect of water content in the water/ChCl.formic acid mixture $(\mathrm{v} / \mathrm{v})$ on glucose and xylose yield. (Hollow column: Glucose yield from pretreated MCC, Shadow column: xylose yield from pretreated corn stover). Reaction conditions: $0.05 \mathrm{~g} \mathrm{MCC}$ or corn stover, $0.1 \mathrm{~g}$ solid acid catalyst and $4 \mathrm{~mL}$ deionized water, $363 \mathrm{~K}$ 
Table 2 Effect of different solvents pretreatment on the composition of corn stover

\begin{tabular}{llllllll}
\hline (\%) & Recoverd & Cellulose & Hemicellulose & AIL & ASL & Lignin & Ash \\
\hline Untreated & 100 & 39.6 & 19.5 & 17.8 & 1.3 & 19.1 & 3.1 \\
Emim.OAc & 83.4 & 43.9 & 21.8 & 12.9 & 1.5 & 14.4 & 3.8 \\
ChCl.Formic acid & 68.2 & 54.3 & 9.7 & 24.1 & 0.8 & 24.9 & 3.6 \\
ChCl.Glycerol & 85.3 & 39.9 & 21.2 & 18.7 & 1.6 & 20.3 & 2.6 \\
ChCl.Urea & 81.4 & 40.5 & 20.3 & 19.9 & 1.3 & 21.2 & 2.7 \\
ChCl.Malonic acid & 76.5 & 48.8 & 13.4 & 21.5 & 0.9 & 22.4 & 3.3 \\
Bmim.Cl & 91.0 & 41.5 & 17.6 & 17.7 & 1.4 & 19.1 & 2.5 \\
\hline
\end{tabular}

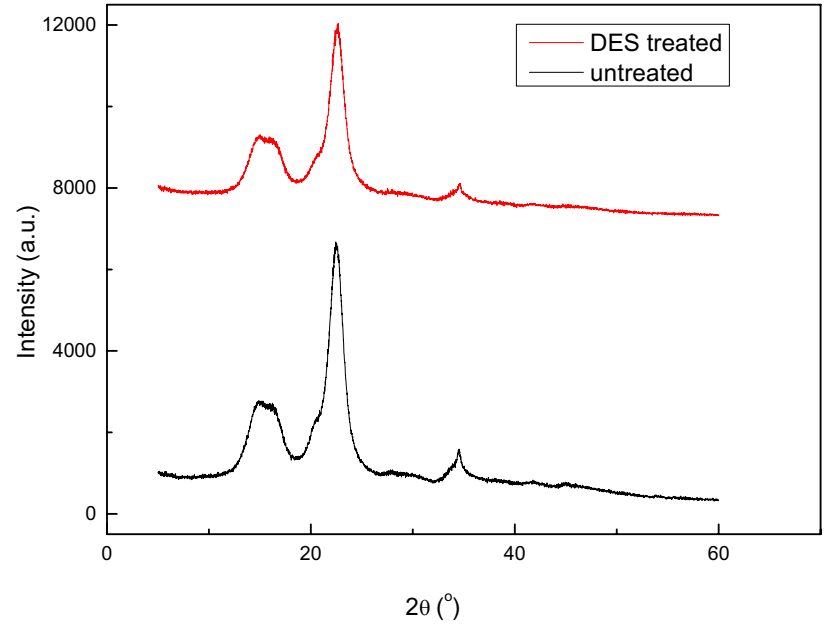

Fig. 8 XRD spectra of the microcrystalline cellulose before and after pretreatment

significantly from 19.0 to $9.7 \%$ after pretreatment by DES with organic acid as the anion. Some lignin was removed, and the lignin content rose from 19.1 to $24.9 \%$. It is clear that the mechanisms of the promotion of the hydrolysis efficiency by the pretreatment process were not the same for ion liquid acetate and DESs. When Emim.OAc was used as the pretreatment solvent, a high fraction of lignin was removed, leading to enhanced glucose yield (the lignin content decreased from 19.1 to $14.4 \%$ based on the total biomass weight). When lignocellulose was pretreated with deep eutectic solvents, relatively little lignin was removed, the lignin-hemicellulose-binding layer was destroyed and a large amount of hemicellulose was removed. Cellulose was exposed to the solvent by swelling and dissolution that apparently reduced the cellulose crystallinity. The change in the cellulose structure was conducive to the hydrolysis of cellulose by solid acid to produce glucose.

Figures 8 and 9 show that the crystallinity of the microcrystalline cellulose and corn stover after pretreatment

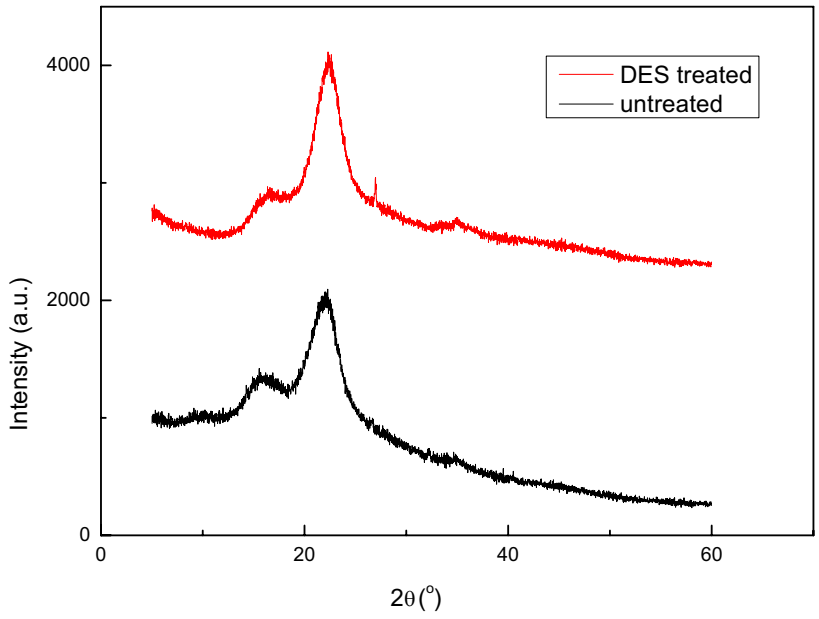

Fig. 9 XRD spectra of the corn stover before and after pretreatment

with the DESs were reduced relative to that of the untreated microcrystalline cellulose. This may facilitate the acid hydrolysis of regenerated cellulose by the solid acid catalyst, leading to increased efficiency of hydrolysis of the pretreated microcrystalline cellulose catalysed by the carbon-based solid acid catalyst. The cellulose crystallinity of the pretreated cellulose in MCC decreased (58.5 to $54.1 \%)$, while cellulose crystallinity of the pretreated cellulose in corn stover increased ( 45.2 to $81 \%$ ), which may be due to the removal of a large amount of amorphous lignin and hemicellulose in the raw materials after the DES pretreatment. The cellulose crystallinity increases after the pretreatment with a deep industrial melt solvent as shown by the XRD results used to provide a rough estimate of the cellulose crystallinity.

As observed from Figs. 10 and 11, the microcrystalline cellulose and corn stover pretreated with DESs were more rough than the untreated material, indicating that after pretreating with $\mathrm{ChCl}$.formic acid, the surfaces of the microcrystalline cellulose and corn stover were loose and 


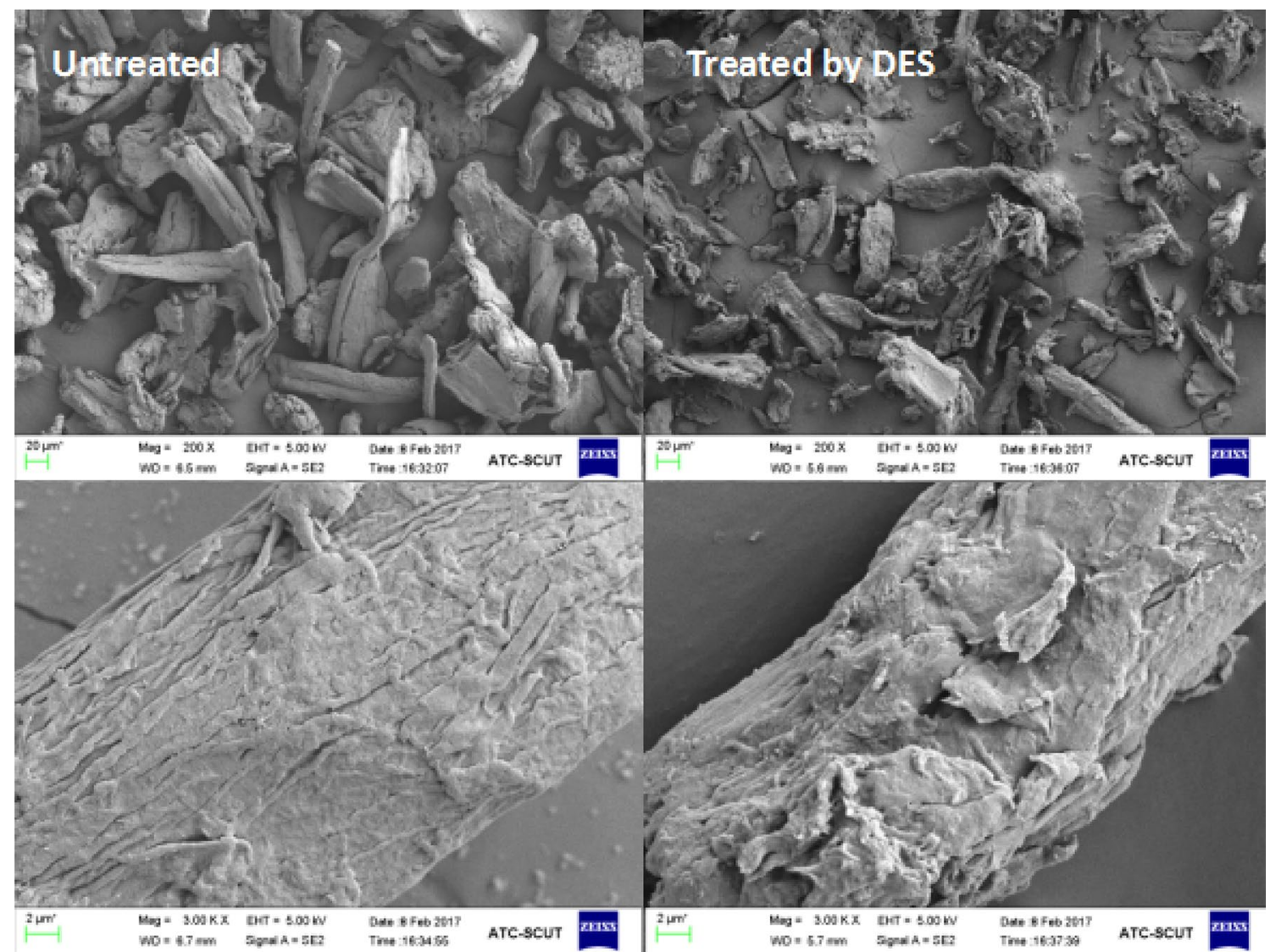

Fig. 10 SEM analysis of the microcrystalline cellulose before and after pretreatment

could more easily contact the solid acid catalyst, thereby promoting the hydrolysis reaction.

\subsection{Applying DES in one-pot hydrolysis}

The glucose yield obtained by one-pot hydrolysis (adding the solid acid catalyst and cellulose to the pretreatment solvent at the same time)was much lower than that obtained by the two-step method. This may be due to the rapid degradation of the glucose to the by-products. It is observed from Fig. 12 that the highest yields of glucose for the hydrolysis of regenerated cellulose pretreated by ILs and DESs were $25.7 \%$ and $21.1 \%$, respectively. Nevertheless, this approach is still promising for simplifying the process and reducing the cost of lignocellulose hydrolysis.

It is observed from Fig. 13 that as the reaction temperature increased, the hydrolysis efficiency of the microcrystalline cellulose in the DESs increased, and the highest glucose yield increased from 21.1 to $23.4 \%$. For the hydrolysis reaction of microcrystalline cellulose catalysed by carbon-based solid acid catalyst in ethyltrimethylimidazole acetate ionic liquid, the glucose yield increased from 25.7 to $28.9 \%$ when the reaction temperature increased from $353 \mathrm{~K}$ to $373 \mathrm{~K}$. Meanwhile, the highest glucose yield when the reaction time was long enough decreased to $18.7 \%$ when the reaction temperature was further increased to $393 \mathrm{~K}$. This may be due to occurrence of strong side effects under high temperature that hindered the accumulation of glucose.

The recyclability of the carbon-based solid acid catalysts in one-pot hydrolysis was evaluated using the production of glucose from MCC as a model reaction. After the first run of the hydrolysis reaction, the catalyst was separated by filtration. The separated catalyst was then collected and washed thoroughly with deionized water prior to being used in another cycle with fresh reactants under the same reaction conditions. As shown in Fig. 14, there were no significant changes in the catalytic activity for catalyst after four runs. After the catalyst was recycled 8 times, the glucose yield decreased by $56 \%$ compared to the first run. 


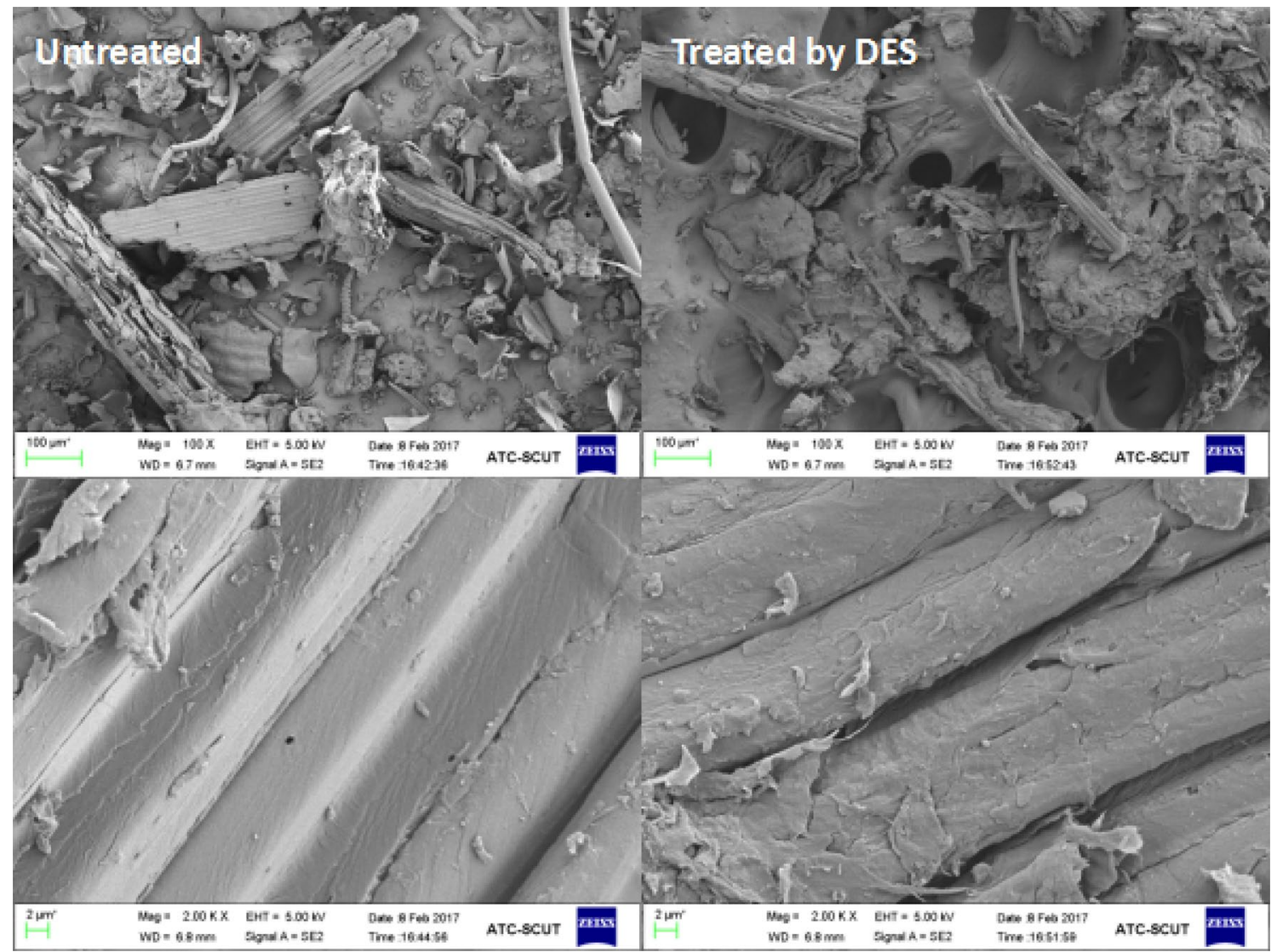

Fig. 11 SEM analysis of corn stover before and after pretreatment

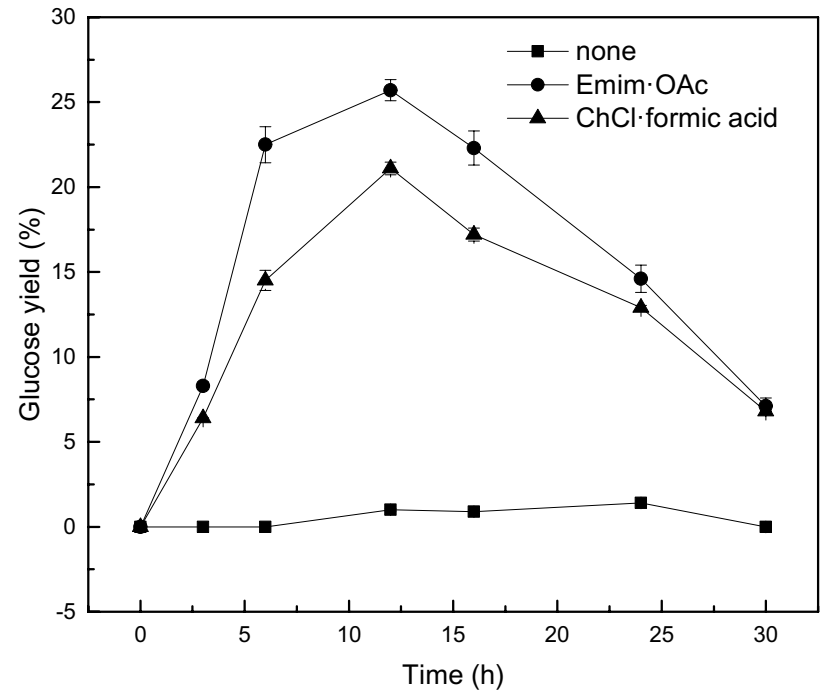

Fig. 12 One-pot hydrolysis of MCC. Reaction conditions: $0.1 \mathrm{~g} \mathrm{MCC,}$ $0.1 \mathrm{~g}$ solid acid catalyst and $4 \mathrm{~mL}$ solvent, $353 \mathrm{~K}$

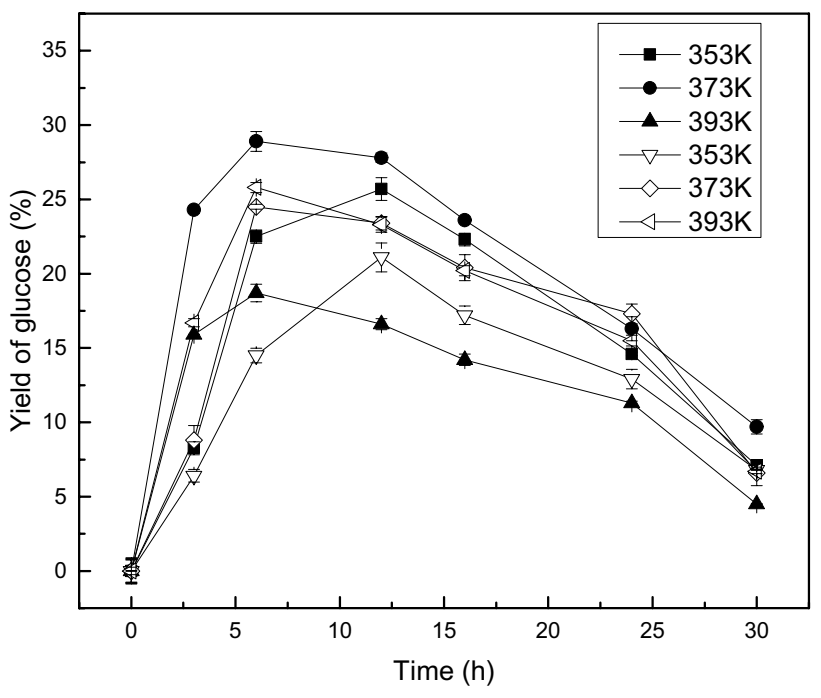

Fig. 13 Glucose yield from MCC reaction at different temperatures with Emim.OAc (closed symbols) and with $\mathrm{ChCl} \cdot$ formic acid (open symbols) in a one-pot reaction. Reaction conditions: $0.1 \mathrm{~g} \mathrm{MCC}$, $0.1 \mathrm{~g}$ solid acid catalyst and $4 \mathrm{~mL}$ solvent 


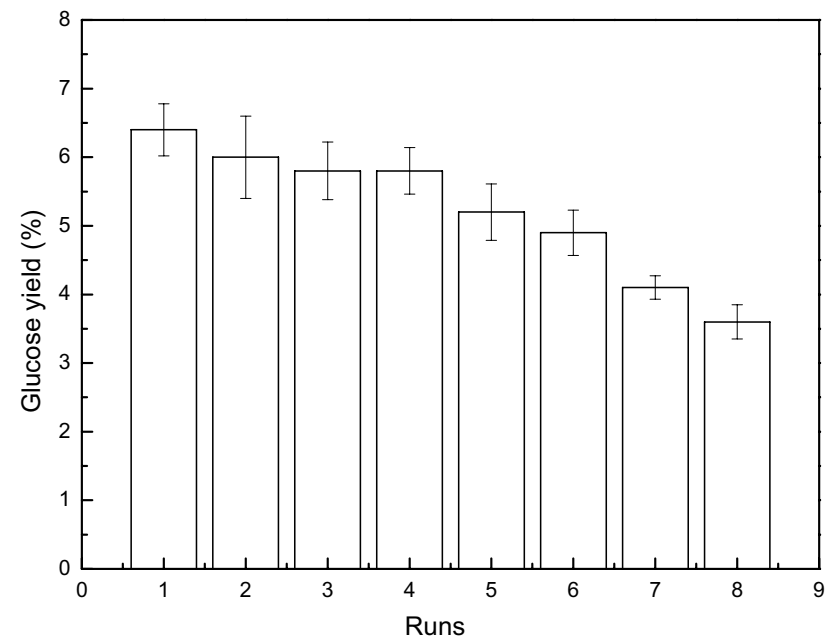

Fig. 14 Reusability of solid catalysts in one-pot reaction. Reaction conditions: $0.1 \mathrm{~g} \mathrm{MCC}, 0.1 \mathrm{~g}$ solid acid catalyst and $4 \mathrm{~mL}$ solvent, $373 \mathrm{~K}, 3 \mathrm{~h}$

An examination of the results presented in Table 3 clearly shows that glucose yield was generally higher for the cellulose hydrolysis catalysed by the enzyme than by the solid acid catalysts (entries 1,3,4,7-9 vs. entries 2,5 and
6). However, a proper separation after the pretreatment was necessary since the subsequent enzyme-catalysed reaction should be conducted under mild conditions. Loss of the enzyme activity is a key problem. The activity loss of the solid acid catalysts was influenced by the reaction conditions. Solid catalysts can mostly maintain their activity at high temperature and in various reaction solvents. This enables the one-pot reaction by applying the solid acid catalyst in the hydrolysis of lignocellulose combined with ILs or DESs pretreatment.

\section{Conclusions}

The efficient pretreatment of microcrystalline cellulose and corn stover by deep eutectic solvents was demonstrated. Hemicellulose was mostly digested in the pretreated process. Glucose and xylose yields in the reaction catalysed by the solid acid catalyst were increased significantly after the pretreatment. The structure of the corn stover was loosened and the cellulose crystallinity was decreased, facilitating the contact of the catalyst with cellulose.

Table 3 Hydrolysis of lignocellulose pretreated by different method and then catalysed by various catalysts

\begin{tabular}{|c|c|c|c|c|c|c|c|c|}
\hline & Substrate & Pretreatment & Catalyst & Ratio & Temp./K & Time/h & Yield of glucose/\% & Ref. \\
\hline 1 & Bamboo particle & $\begin{array}{l}\text { Pentanol-water } \\
(80 \% \mathrm{v} / \mathrm{v})\end{array}$ & Enzyme & 20FPU/g/glucan & 323 & 72 & 87.3 & {$[31]$} \\
\hline 2 & MCC & None & $\begin{array}{l}\text { Sulphonated } \\
\text { hydrochars }\end{array}$ & $1: 3(\mathrm{~g} / \mathrm{g})$ & 423 & 14 & 33.7 (TRS) & [32] \\
\hline 3 & sugarcane bagasse & $\begin{array}{l}\text { Step 1: } 1 \% \mathrm{H}_{2} \mathrm{SO}_{4} \\
\text { Step 2: } 60 \% \text { etha- } \\
\text { nol }+0.5 \% \mathrm{NaOH}\end{array}$ & Enzyme +Tween80 & $20 \mathrm{FPU}+150 \mathrm{mg} / \mathrm{g}$ & 323 & 72 & 84.5 & [33] \\
\hline 4 & Wheat straw & $4 \% \mathrm{NaOH}$ & Enzyme & $35 \mathrm{FPU} / \mathrm{g}$ & 328 & 72 & $\begin{array}{l}\text { 87.2(cellulose } \\
\text { conv.) }\end{array}$ & {$[34]$} \\
\hline 5 & Corncob & Ball-milled & $\begin{array}{l}\text { Magnetic Solid } \\
\text { Acid }\end{array}$ & $5: 1(\mathrm{~g} / \mathrm{g})$ & 393 & 0.5 & 12.88 & {$[35]$} \\
\hline 6 & Cellulose-Sigma & Ball-milled & $\begin{array}{l}\text { Carbonaceous } \\
\text { Solid Acid + } 0.02 \\
\text { wt } \% \mathrm{H}_{2} \mathrm{SO}_{4}\end{array}$ & $2: 1$ & 473 & 1 & 71.9 & {$[36]$} \\
\hline 7 & Wood powder & $\mathrm{Eim} \cdot \mathrm{Cl}$ & Enzyme & $25 \mathrm{FPU} / \mathrm{g}$ & 323 & 72 & 75 & [37] \\
\hline 8 & Sugarcane bagasse & {$[\mathrm{Cho}][\mathrm{Orn}]+\mathrm{FeCl}_{2}$} & Enzyme & $20 \mathrm{FPU} / \mathrm{g}$ & 323 & 48 & 31.7 & [38] \\
\hline 9 & Eucalyptus & $\mathrm{ChCl} \cdot \mathrm{LA}$ & Enzyme & $15 \mathrm{FPU} / \mathrm{g}$ & - & 72 & 94.3 & [39] \\
\hline 10 & Corn straw & ChCl.Formic acid & $\begin{array}{l}\text { Carbon based acid } \\
\text { catalyst }\end{array}$ & $1: 2(\mathrm{~g} / \mathrm{g})$ & 363 & 24 & 40.8 (TRS) & This work \\
\hline 11 & MCC & $\begin{array}{l}\text { ChCl.Formic acid } \\
\text { (30\% water) }\end{array}$ & $\begin{array}{l}\text { Carbon based acid } \\
\text { catalyst }\end{array}$ & $1: 2(\mathrm{~g} / \mathrm{g})$ & 363 & 24 & 46.4 & This work \\
\hline
\end{tabular}


Acknowledgements The authors wish to acknowledge financial support from the Science and Technology Project of Guangzhou City (201707010537), GDAS' Project of Science and Technology Development (2019GDASYL-0103042) and Zhihui Zhengzhou·1125 Jucai Project.

\section{Compliance with ethical standards}

Conflicts of interest There are no conflicts to declare.

Open Access This article is licensed under a Creative Commons Attribution 4.0 International License, which permits use, sharing, adaptation, distribution and reproduction in any medium or format, as long as you give appropriate credit to the original author(s) and the source, provide a link to the Creative Commons licence, and indicate if changes were made. The images or other third party material in this article are included in the article's Creative Commons licence, unless indicated otherwise in a credit line to the material. If material is not included in the article's Creative Commons licence and your intended use is not permitted by statutory regulation or exceeds the permitted use, you will need to obtain permission directly from the copyright holder. To view a copy of this licence, visit http://creativecommons .org/licenses/by/4.0/.

\section{References}

1. Cai C, Qiu X, Lin X, Lou H, Pang Y, Yang D, Chen S, Cai K (2016) Improving enzymatic hydrolysis of lignocellulosic substrates with pre-hydrolysates by adding cetyltrimethylammonium bromide to neutralize lignosulfonate. Biores Technol 216:968-975. https://doi.org/10.1016/j.biortech.2016.06.043

2. Bi S, Peng L, Chen K, Zhu Z (2016) Enhanced enzymatic saccharification of sugarcane bagasse pretreated by combining $\mathrm{O}-2$ and $\mathrm{NaOH}$. Biores Technol 214:692-699. https://doi.org/10.1016/j. biortech.2016.05.041

3. Jain A, Wei Y, Tietje A (2016) Biochemical conversion of sugarcane bagasse into bioproducts. Biomass Bioenerg 93:227-242. https://doi.org/10.1016/j.biombioe.2016.07.015

4. Liu Z, Li L, Liu C, Xu A (2017) Saccharification of cellulose in the ionic liquids and glucose recovery. Renew Energy 106:99-102. https://doi.org/10.1016/j.renene.2017.01.023

5. Lynam JG, Reza MT, Vasquez VR, Coronella CJ (2012) Pretreatment of rice hulls by ionic liquid dissolution. Biores Technol 114:629-636. https://doi.org/10.1016/j.biortech.2012.03.004

6. Li H-Y, Chen X, Wang C-Z, Sun S-N, Sun R-C (2016) Evaluation of the two-step treatment with ionic liquids and alkali for enhancing enzymatic hydrolysis of eucalyptus: chemical and anatomical changes. Biotechnol Biofuels. https://doi.org/10.1186/s1306 8-016-0578-y

7. Nemestothy N, Megyeri G, Bakonyi P, Lakatos P, Kook L, Polakovic M, Gubicza L, Belafi-Bako K (2017) Enzyme kinetics approach to assess biocatalyst inhibition and deactivation caused by bmim Cl ionic liquid during cellulose hydrolysis. Biores Technol 229:190-195. https://doi.org/10.1016/j.biortech.2017.01.004

8. Gunny AAN, Arbain D, Nashef EM, Jamal P (2015) Applicability evaluation of deep eutectic solvents-cellulase system for lignocellulose hydrolysis. Biores Technol 181:297-302. https://doi. org/10.1016/j.biortech.2015.01.057

9. Elgharbawy AA, Alam MZ, Moniruzzaman M, Goto M (2016) Ionic liquid pretreatment as emerging approaches for enhanced enzymatic hydrolysis of lignocellulosic biomass. Biochem Eng J 109:252-267. https://doi.org/10.1016/j.bej.2016.01.021

10. Zhang S, Sun J, Zhang X, Xin J, Miao Q, Wang J (2014) lonic liquid-based green processes for energy production. Chem Soc Rev 43(22):7838-7869. https://doi.org/10.1039/c3cs60409h

11. Ninomiya K, Omote S, Ogino C, Kuroda K, Noguchi M, Endo T, Kakuchi R, Shimizu N, Takahashi K (2015) Saccharification and ethanol fermentation from cholinium ionic liquid-pretreated bagasse with a different number of post-pretreatment washings. Biores Technol 189:203-209. https://doi.org/10.1016/j.biort ech.2015.04.022

12. Fu D, Mazza G (2011) Aqueous ionic liquid pretreatment of straw. Biores Technol 102(13):7008-7011. https://doi.org/10.1016/j. biortech.2011.04.049

13. Brandt A, Ray MJ, To TQ, Leak DJ, Murphy RJ, Welton T (2011) Ionic liquid pretreatment of lignocellulosic biomass with ionic liquid-water mixtures. Green Chem 13(9):2489-2499. https:// doi.org/10.1039/c1gc15374a

14. Bahcegul E, Apaydin S, Haykir NI, Tatli E, Bakir U (2012) Different ionic liquids favor different lignocellulosic biomass particle sizes during pretreatment to function efficiently. Green Chem 14(7):1896-1903. https://doi.org/10.1039/c2gc35318k

15. Li C, Tanjore D, He W, Wong J, Gardner JL, Thompson VS, Yancey NA, Sale KL, Simmons BA, Singh S (2015) Scale-up of ionic liquidbased fractionation of single and mixed feedstocks. Bioenergy Res 8(3):982-991. https://doi.org/10.1007/s12155-015-9587-0

16. Huang $Q$, Wang $Q$, Gong Z, Jin G, Shen H, Xiao S, Xie H, Ye S, Wang J, Zhao ZK (2013) Effects of selected ionic liquids on lipid production by the oleaginous yeast Rhodosporidium toruloides. Biores Technol 130:339-344. https://doi.org/10.1016/j.biort ech.2012.12.022

17. Li A-L, Hou X-D, Lin K-P, Zhang X, Fu M-H (2018) Rice straw pretreatment using deep eutectic solvents with different constituents molar ratios: biomass fractionation, polysaccharides enzymatic digestion and solvent reuse. J Biosci Bioeng 126(3):346-354. https://doi.org/10.1016/j.jbiosc.2018.03.011

18. Procentese A, Johnson E, Orr V, Campanile AG, Wood JA, Marzocchella A, Rehmann L (2015) Deep eutectic solvent pretreatment and subsequent saccharification of corncob. Biores Technol 192:31-36. https://doi.org/10.1016/j.biortech.2015.05.053

19. Hou X-D, Feng G-J, Ye M, Huang C-M, Zhang Y (2017) Significantly enhanced enzymatic hydrolysis of rice straw via a high-performance two-stage deep eutectic solvents synergistic pretreatment. Biores Technol 238:139-146. https://doi. org/10.1016/j.biortech.2017.04.027

20. Hou X-D, Li A-L, Lin K-P, Wang Y-Y, Kuang Z-Y, Cao S-L (2018) Insight into the structure-function relationships of deep eutectic solvents during rice straw pretreatment. Biores Technol 249:261-267. https://doi.org/10.1016/j.biort ech.2017.10.019

21. Yang HY, Zhou Y, Tong DS, Yang M, Fang $\mathrm{K}$, Zhou CH, Yu WH (2020) Catalytic conversion of cellulose to reducing sugars over clay-based solid acid catalyst supported nanosized $\mathrm{SO}_{4}{ }^{-}-\mathrm{ZrO}_{2}$. Appl Clay Sci 185:105376-105383. https://doi.org/10.1016/j. clay.2019.105376

22. Wang S, Zhang LQ, Sima GB, Cui Y, Gan LH (2019) Efficient hydrolysis of bagasse cellulose to glucose by mesoporous carbon solid acid derived from industrial lignin. Chem Phys Lett 736:136808136814. https://doi.org/10.1016/j.cplett.2019.136808

23. Irwan K, Akihiro Y, Nichaboon C, Asep B, Yutaka K, Abuliti A, Guan GQ (2019) Hydrolysis of cellulose and woody biomass over sustainable weak-acid carbon catalysts from alkaline lignin. Fuel Process Technol 196:106175-106181. https://doi.org/10.1016/j. fuproc.2019.106175

24. Xu G-C, Ding J-C, Han R-Z, Dong J-J, Ni Y (2016) Enhancing cellulose accessibility of corn stover by deep eutectic solvent 
pretreatment for butanol fermentation. Biores Technol 203:364369. https://doi.org/10.1016/j.biortech.2015.11.002

25. Hu S, Smith TJ, Lou W, Zong M (2014) Efficient hydrolysis of cellulose over a novel sucralose-derived solid acid with cellulosebinding and catalytic sites. J Agric Food Chem 62(8):1905-1911. https://doi.org/10.1021/jf405712b

26. Li W, Teck N, Gek C, Adeline S (2012) Regression analysis on ionic liquid pretreatment of sugarcane bagasse and assessment of structural changes. Biomass Bioenerg 36:160-169. https://doi. org/10.1016/j.biombioe.2011.10.033

27. Florindo C, Oliveira FS, Rebelo LPN, Fernandes AM, Marrucho IM (2014) Insights into the synthesis and properties of deep eutectic solvents based on cholinium chloride and carboxylic acids. ACS Sustain Chem Eng 2(10):2416-2425. https://doi. org/10.1021/sc500439w

28. Thi S, Lee KM (2019) Comparison of deep eutectic solvents (DES) on pretreatment of oil palm empty fruit bunch (OPEFB): cellulose digestibility, structural and morphology. Biores Technol 282:525-529. https://doi.org/10.1016/j.biortech.2019.03.065

29. Zhao M-J, Xu Q-Q, Yin J-Z, Lu J-B, Luo W-T, Liu J-T, Zhou D (2019) Pretreatment of corn cob in EMIM OAc and EMIM OAc/ethanol (water). Bioprocess Biosyst Eng 42(8):1273-1283. https://doi. org/10.1007/s00449-019-02126-5

30. Su TC, Zeng J, Gao HY, Jiang LQ, Bai XZ, Zhou HX, Xu FX (2020) One-pot synthesis of a chemically functional magnetic carbonaceous acid catalyst for fermentable sugars production from sugarcane bagasse. Fuel 262:116512-116519. https://doi. org/10.1016/j.fuel.2019.116512

31. Liu J, Hu H, Gong Z, Yang G, Li R, Chen L, Huang L, Luo X (2019) Near-complete removal of non-cellulosic components from bamboo by 1-pentanol induced organosolv pretreatment under mild conditions for robust cellulose enzymatic hydrolysis. Cellulose 26(6):3801-3814. https://doi.org/10.1007/s10570-01902334-y

32. Chen Y, Ai X, Huang B, Huang M, Huang Y, Lu Y (2017) Consecutive preparation of hydrochar catalyst functionalized in situ with sulfonic groups for efficient cellulose hydrolysis. Cellulose 24(7):2743-2752. https://doi.org/10.1007/s10570-017-1306-x
33. Zhang H, Wei W, Zhang J, Huang S, Xie J (2018) Enhancing enzymatic saccharification of sugarcane bagasse by combinatorial pretreatment and Tween 80. Biotechnol Biofuels 11:309. https ://doi.org/10.1186/s13068-018-1313-7

34. Zheng Q, Zhou T, Wang Y, Cao X, Wu S, Zhao M, Wang H, Xu M, Zheng B, Zheng J, Guan X (2018) Pretreatment of wheat straw leads to structural changes and improved enzymatic hydrolysis. Sci Rep. https://doi.org/10.1038/s41598-018-19517-5

35. Zhu Y, Huang J, Sun S, Wu A, Li H (2019) Effect of dilute acid and alkali pretreatments on the catalytic performance of bambooderived carbonaceous magnetic solid acid. Catalysts. https:// doi.org/10.3390/catal9030245

36. Qiu M, Bai C, Yan L, Shen F, Qi X (2018) Efficient mechanochemical-assisted production of glucose from cellulose in aqueous solutions by carbonaceous solid acid catalysts. Acs Sustain Chem Eng 6(11):13826-13833. https://doi.org/10.1021/acssu schemeng.8b01910

37. Hossain MM, Rawal A, Aldous L (2019) Aprotic vs protic ionic liquids for lignocellulosic biomass pretreatment: anion effects, enzymatic hydrolysis, solid-state NMR, distillation, and recycle. ACS Sustai Chem Eng. https://doi.org/10.1021/acssuschem eng.8b05987

38. Xu J, Xu J, Zhang S, Xia J, Liu X, Chu X, Duan J, Li X (2018) Synergistic effects of metal salt and ionic liquid on the pretreatment of sugarcane bagasse for enhanced enzymatic hydrolysis. Biores Technol 249:1058-1061. https://doi.org/10.1016/j.biort ech.2017.10.018

39. Shen X-J, Wen J-L, Mei Q-Q, Chen X, Sun D, Yuan T-Q, Sun R-C (2019) Facile fractionation of lignocelluloses by biomass-derived deep eutectic solvent (DES) pretreatment for cellulose enzymatic hydrolysis and lignin valorization. Green Chem 21(2):275283. https://doi.org/10.1039/c8gc03064b

Publisher's Note Springer Nature remains neutral with regard to jurisdictional claims in published maps and institutional affiliations. 